\title{
REDESAIN KEMASAN DALAM MENINGKATKAN BRAND AWARNESS PRODUK UNGGULAN UKM CILODONG BERKARYA
}

\author{
Yani Hendrayani ${ }^{1}$ dan Hermina Manihuruk ${ }^{2}$ \\ ${ }^{1}$ Jurusan Ilmu Komunikasi Fakultas Ilmu Sosial dan Ilmu Politik, Universitas Pembangunan Nasional "Veteran" \\ Jakarta \\ E-mail : yanihendrayani@upnvj.ac.id \\ 2Jurusan Ilmu Komunikasi Fakultas Ilmu Sosial dan Ilmu Politik, Universitas Pembangunan Nasional "Veteran" \\ Jakarta \\ E-mail : herminamanihuruk@upnvj.ac.id
}

\begin{abstract}
Product packaging design is one important factor that can strengthen the branding of MSME businesses in increasingly fierce business competition. Attractive and quality packaging design is the differentiator from competitors. For this reason, the idea of product packaging for UKM Cilodong Berkarya needs to get attention for the redesign of each product to be marketed. For this reason, community engagement is carried out to find out the extent of the understanding of the UKM Cilodong Berkarya entrepreneurs regarding the importance of Product Packaging Design and continued with the design of the right packaging design for its products to enhance brandawarness and superior products. The purpose of this activity is to build brand awareness from the redesign of product packaging products that were launched by UKM Cilodong Berkarya Berkarya Kota Depok. The method of activity through mentoring and training in product packaging redesigning is more attractive to consumers by choosing one of the superior products. The target of the output is to make an alternative product packaging for one of the superior products, namely Alevera Tea, which was launched by UKM Cilodong Berkarya in the City of Depok. The results of community engagement regarding packaging redesign are related to the shape, structure, material, color, image, typography, and design elements with product information so that the product can be marketed. Redesign of packaging in the form of designing old packaging into new packaging to make it more attractive, so that it has the maximum function applicable to wrapping, protecting, sending, issuing, storing, identifying, and differentiating a product on the market.
\end{abstract}

Keywords: Package redesign; superior SME products; brand awareness

\begin{abstract}
ABSTRAK
Desain kemasan produk merupakan salah satu faktor penting yang dapat menguatkan branding usaha UMKM dalam persaingan bisnis yang semakin ketat. Desain kemasan yang menarik dan berkualitas menjadi pembeda dari kompetitor. Untuk itu ide kemasan produk UKM Cilodong Berkarya Berkarya perlu mendapatkan perhatian untuk redesain pada setiap produk yang akan dipasarkan. Untuk itu dilakukan pengabdian masyarakat untuk mengetahui sejauh mana pemahaman para pengusaha UKM Cilodong Berkarya terkait tentang pentingnya Desain Kemasan Produk dan dilanjutkan dengan perancangan desain kemasan yang tepat bagi produk produknya untuk meningkatkan brandawarness dan produk unggulan. Adapun tujuan kegiatan ini adalah membangun brand awareness (kesadaran akan merek) dari redesaign kemasan produk produk yang diluncurkan UKM Cilodong Berkarya Berkarya Kota Depok. Metode kegiatan melalui pendampingan dan pelatihan redesigning kemasan produk yang lebih menarik konsumen dengan memilih salah satu produk unggulan. Target luaran adalah dibuatkan alternatif kemasan kemasan produk untuk salah satu produk unggulan yaitu teh aloevera yang diluncurkan UKM Kota Cilodong Berkarya Kota Depok. Hasil dari pengabdian masyarakat tentang redesain kemasan berkaitan pada bentuk, struktur, material, warna, citra, tipografi, dan elemen elemen desain dengan informasi produk agar produk dapat dipasarkan. Redesain kemasan berupa mendesain kemasan lama menjadi kemasan baru agar lebih menarik, sehingga memiliki fungsi yang maksimal berlaku untuk membungkus, melindungi, mengirim, mengeluarkan, menyimpan, mengidentifikasi, dan membedakan sebuah produk di pasar.
\end{abstract}

Kata kunci : Redesain kemasan; produk unggulan UKM; brand awarnesss

\section{PENDAHULUAN}

Setiap organisasi tentunya memiliki strategi pemasaran yang harus dijalankan dalam melaksanakan kegiatan bisnisnya (Antti, Madupu, Yavas, \& Babakus, 2005). Strategi merupakan sarana organisasi yang digunakan untuk mencapai tujuannya. Salah satu bentuk dari strategi 
bisnis adalah strategi pemasaran. Tetapi banyak kasus UKM di Indonesia yang tidak dapat melakukan strategi pemasaran yang tepat. Cenderung UKM di Indonesia hanya "menunggu konsumen" dan monoton dalam melakukan kegiatan pemasaran. Menurut Primiana dalam bukunya Menggerakan Sektor Rill UKM \& Industri (2009), selain permodalan yang menjadi pokok permasalahan bagi UKM berkaitan dengan pemasaran, lebih dikarenakan: Sulitnya akses pasar dikarenakan keterbatasan-keterbatasan antara lain membaca selera pasar, mengenal pesaing dan produknya, memposisikan produknya di pasar, mengenal kelemahan produknya diantara produk pesaing.

Keterbatasan SDM. Untuk usaha Mikro dan Kecil pada umumnya pemilik masih melakukan semua kegiatan sendiri atau dibantu beberapa pegawai seperti produksi atau pengawasan produksi, sehingga mencari pasar menjadi terbengkalai.

1. Strandarisasi produk lemah, hal ini menyebabkan pesanan dikembalikan (retur) dikarenakan kualitas produk yang dihasilkan spesifiknya tidak sesuai dengan pada saat pesan.

2. Hilangnya kepercayaan pelanggan akibat ketidakmampuan memenuhi permintaan dalam jumlah besar, antara lain dikarenakan tidak tersedianya dana untuk memenuhi permintaan tersebut.

Berdasarkan galeriukm.web.id, Permasalahan mendasar yang sering dihadapi pemilik Usaha Kecil adalah lemahnya penetrasi pasar dan kurang luasnya jangkauan wilayah pemasaran. Karena itu untuk memajukan usaha kecil yang memiliki daya saing yang kuat adalah dengan membangun strategi pemasaran yang baik dan tepat sasaran. Pemasaran merupakan upaya mengatur strategi dan cara agar konsumen mau mengeluarkan uang yang mereka miliki untuk menggunakan produk atau jasa yang dimiliki sebuah perusahaan, dalam hal ini usaha kecil dan menengah. Dengan strategi pemasaran yang baik posisi usaha kecil dan menengah menjadi kuat dan patut diperhitungkan dalam kegiatan ekonomi nasional yang akhirnya membawa keuntungan bagi usaha tersebut.

Desain kemasan produk merupakan salah satu faktor penting yang dapat menguatkan branding usaha UMKM dalam persaingan bisnis yang semakin ketat. Desain kemasan yang menarik dan berkualitas menjadi pembeda dari kompetitor. Melalui desain kemasan produk, dapat menyampaikan informasi mengenai brand, logo, kualitas, dan lain-lain. Hal ini juga yang akan menarik perhatian pelanggan untuk jatuh cinta pada produk produk UMKM.Sebenarnya, kemasan menarik tidak harus mahal atau banyak hiasan, tetapi hanya perlu menjadi kreatif dan membuat keseimbangan antara efektivitas dan kreativitas.Ini akan membuat barang dagangan yang dihasilkan UMKM lebih stand out serta menarik perhatian orang yang melihat. Artinya, konsumen akan terikat untuk selalu mengingat produk tersebut.

Desain kemasan menarik dan unik pasti punya semacam karakter yang bisa membedakan dengan produk lainnya. Adapun fungsi desain kemasan yang menarik adalah merefleksikan produk itu sendiri dan karakter bisnis yang dijalani. Bagi pelaku bisnis yang sudah berpengalaman, tentu hal ini sangat diperhatikan karena dapat membantu proses pemasaran.

Beberapa fungsi desain kemasan produk yang menarik, antara lain :

1. Membantu pemasaran karena dalam desain kemasan tersebut tercantum informasi penting seperti merek bisnis, jenis produk, penjelasan produk, expire date, kandungan gizi, serta alamat dan keterangan produsen. 
2. Meningkatkan kualitas serta brand awereness produk tersebut karena makin dikenal sekaligus dipercaya konsumen dan calon konsumen baru.

3. Menjaga kualitas barang di dalamnya seperti makanan tetap aman, pakaian agar tidak rusak, alat elektronik tetap terjamin dan bisa digunakan.

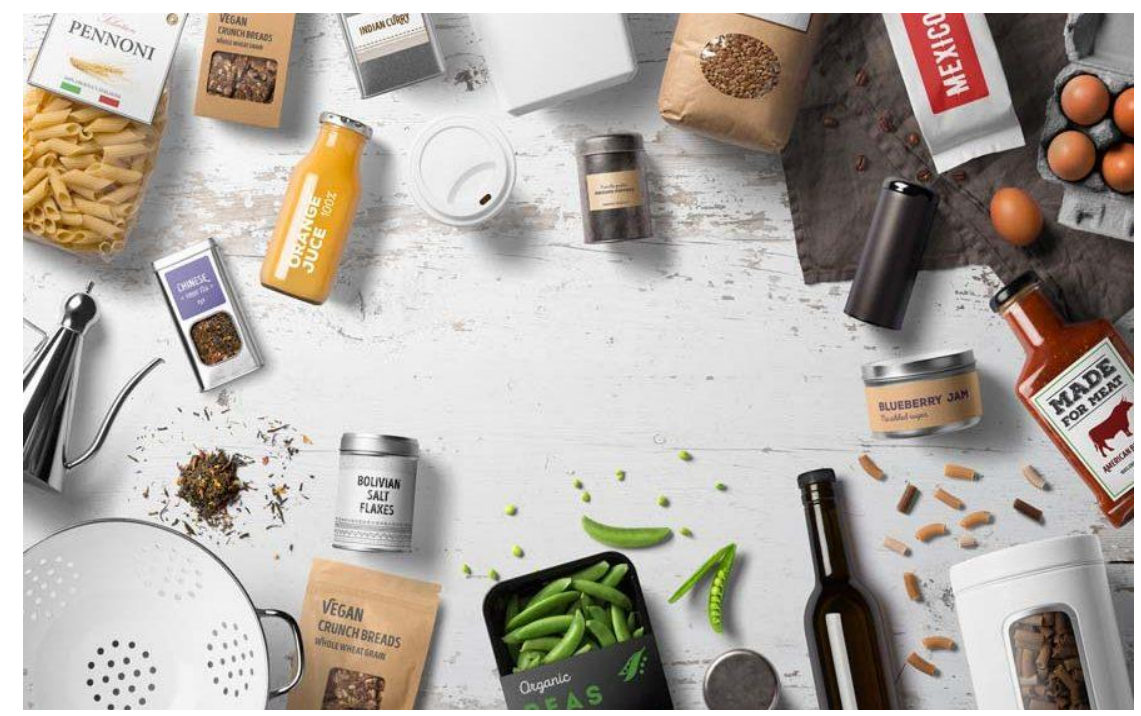

Gambar 1. Contoh-Contoh Kemasan Produk

Berdasarkan kondisi riil sebagaimana yang dijelaskan dalam analisis situasi, maka permasalahan yang dihadapi mitra dapat dibagi menjadi dua, yaitu permasalahan promosi dan pemasaran dan minimnya brand awarness. Permasalahan promosi dan pemasaran adalah ketidak mampuan mitra tidak dapat melakukan strategi promosi dan pemasaran yang tepat. cenderung UKM di Indonesia hanya "menunggu konsumen" dan monoton dalam melakukan kegiatan pemasaran.

Sedangkan permasalahan brand awareness diklasifikasi menjadi keterbatasan-keterbatasan antara lain membaca selera pasar, mengenal pesaing dan produknya, memposisikan produknya di pasar, mengenal kelemahan produknya diantara produk pesaing demi menciptakan produk unggulan di UKM Kota Depok. Prospek pemasaran hasil olahan produk di kelompok UKM Cilodong Berkarya Kota Depok saat ini masih sangat cerah. Banyak produk hasil olahan sangat diminati dan disukai oleh konsumen/masyarakat dikarenakan cita rasanya dan variasi hasil olahan yang beragam. Namun, diperlukan perhatian bagaimana penampilan yang membungkus produk UKM tersebut. Jika produk UKM yang bagus dan menarik, tetapi tidak membungkusnya dengan desain kemasan yang indah, jelas tidak akan mendapatkan perhatian pelanggan. permasalahan- tersebut dapat diuraikan dalam

Tabel 1. Permasalahan Kemasan Produk UMKM

\begin{tabular}{|c|c|c|c|}
\hline Jenis & Aspek & Mitra & Solusi \\
\hline $\begin{array}{l}\text { Perlu Redesign } \\
\text { Kemasan Produk } \\
\text { Yang Lebih } \\
\text { Menarik }\end{array}$ & Perfoma Produk & $\begin{array}{l}\text { Produk Produk } \\
\text { diluncurkan oleh UKM Kota } \\
\text { Depok perlu ada retouch atau } \\
\text { redesigning kemasan produk } \\
\text { yang lebih menarik konsumen. }\end{array}$ & $\begin{array}{l}\text { Perlu ada pendampingan } \\
\text { dan pelatihan redesigning } \\
\text { kemasan produk yang lebih } \\
\text { menarik konsumen. }\end{array}$ \\
\hline
\end{tabular}


Uraian permasalahan mitra adalah Perlu Redesain Kemasan Produk Yang Lebih Menarik. Hasil wawancara dengan mitra menunjukkan salah satu faktor yang penting dalam pemasaran yaitu promosi. Promosi adalah usaha-usaha sadar untuk melakukan sosialisasi, penerangan, dan pemberitahuan kepada masyarakat tentang berbagai informasi, yang biasanya mengenai berbagai produk yang ditawarkan. Aktivitas promosi melibatkan berbagai bentuk dan variasi yang sangat beragam. Tinggal bagaimana para pengelola melakukan berbagai promosi kreatif sesuai dengan kebutuhan dan anggaran promosi yang disediakan. Membuat kemasan produk yang baik dan menarik merupakan salah satu bentuk promosi yang cukup baik dan efektif. Produk Produk yang diluncurkan oleh UKM Cilodong Berkarya Kota Depok perlu ada retouch atau redesigning kemasan produk yang lebih menarik konsumen.

Berdasarkan uraian di atas maka, suatu desain kemasan selain harus memperhatikan nilai ekstetika, yaitu penempatan dan fungsi setiap material yang terlekat pada desain kemasan tersebut. Untuk itu ide kemasan produk UKM Cilodong Berkarya Berkarya perlu mendapatkan perhatian untuk redesain pada setiap produk yang akan dipasarkan. Maka akan dilakukan pengabdian masyarakat untuk mengetahui sejauh mana pemahaman para pengusaha UKM Cilodong Berkarya terkait tentang pentingnya Desain Kemasana Produk dan dilanjutkan dengan perancangan desain kemasan yang tepat bagi produk produknya untuk meningkatkan brandawarness dan produk unggulan

\section{METODE}

\section{Metode Pelaksanaan}

Metode pelaksanaan pada program pengabdian masyarakat ini, terdiri dari dua tahapan pelaksanaan yaitu :

a. Tahap pertama, untuk pemecahan masalah terbatasnya pemahaman diantara para pelaku usaha dalam UKM Cilodong Berkarya Kota Depok, maka Tim merencanakan pendekatan berupa Pelatihan di kelas.

b. Tahap kedua, untuk meningkatkan pengetahuan dan keterampilan bagaimana desaign kemasan yang menarik yaitu pemberian praktek langsung serta Simulasi.

c. Tahap ketiga, membangun sikap apresiatif mereka dengan diskusi, tanya jawab dan problem solving dari berbagai hambatan dan kendala bagaimana desaign kemasan produk selama ini yang sering mereka hadapi diantara para pelaku usaha UKM Cilodong Berkarya Kota Depok

d. Tahap keempat, memilih salah satu produk unggulan UKM Cilodong Berkarya untuk diredesain kemasan produknya yaitu teh aloe vera.

\section{Prosedur Kerja}

Adapun tahapan pelaksanaan Program yaitu sebagi berikut:

Jadwal kerja kegiatan ini terdiri dari beberapa tahap yaitu:

1. Persiapan, Tahap ini dilakukan setelah persetujuan kegiatan ini direalisasikan yang menyangkut: waktu, tempat, dan keperluan yang dibutuhkan.

2. Pelaksanaan pelatihan dan melakukan Redesain Kemasan Produk untuk produk unggulan UKM Cilodong Berkarya, Tahap ini adalah kegiatan utama pengetahuan dan praktek Desaign kemasan produk yang menarik dalam menangkap tantangan dan peluang mengembangkan market

3. Evaluasi Kegiatan, Tahap ketiga ini merupakan rangkaian kegiatan berupa evaluasi terhadap kegiatan tahap kedua dan persiapan laporan.

a. Pembuatan Laporan 
- Pembuatan Laporan Awal, Pembuatan laporan awal disesuaikan dengan hasil yang telah dicapai selama melakukan pemahaman terhadap para pelaku usaha agar memiliki konsep promosi dan kampanye melalui Redesaining Produk

- Revisi Laporan Revisi laporan dilakukan apabila terjadi kesalahan pada pembuatan laporan awal.

- Pembuatan Laporan Akhir, Pembuatan laporan akhir dilakukan setelah melakukan revisi laporan agar dalam penyusunan laporan akhir diperoleh hasil yang lebih baik.

\section{b. Rancangan Evaluasi}

Adapun rancangan evaluasi dan indikator pelaksanaan kegiatan ini adalah berupa evalusi pasca kegiatan yang rencananya akan dilaksanakan setiap bulan selama empat bulan bertutur-turut dengan jadwal sebagai berikut:

- Bulan kesatu: Peninjauan ke lokasi sebagai tahap awal melihat potensi individual dalam pengenalan dasar pengetahuan dan keterampilan bagaimana desaign kemasan produk yang menarik.

- Bulan kedua: Peninjauan ke lokasi dan wawancara serta penerapan desaign kemasan untuk mengembangkan bisnis para pelaku usaha.

- Bulan ketiga: Peninjauan ke lokasi dan wawancara rencana para pelaku usaha untuk melakukan redesain produk dan memilih produk yang menjadi produk unggulan UKM Cilodong Berkarya yaitu teh aloevera.

- Bulan keempat: Peninjauan ke lokasi Redesain Kemasan Produk yang telah diterapkan oleh para pelaku usaha untuk meningkatkan penjualan di UKM Cilodong Berkarya Kota Depok.

\section{HASIL DAN PEMBAHASAN}

\section{Pelaksanaan pelatihan Redesain Kemasan Produk}

Pelaksanaan kegiatan pengabdian ini telah dilaksanakan dalam dua kali pertemuan dengan sejumlah 20 peserta yang telah menjadi anggota UKM Cilodong Berkarya. Pertemuan ini dilaksanakan selama 5 jam dibagi sebanyak 3 sessi untuk penyampaian materinya. Pertemuan pertama menghadirkan anggota UKM Cilodong Berkarya di Gedung Pertemuan Taman Aloevera, Cilodong Depok. Kegiatan ini berlangsung pada tanggal 10 Juli 2019. Peserta kegiatan membawa contoh produk yang telah menjadi usaha mereka selama ini. Pada kegiatan ini, sebagian produk dipamerkan di stand yang sudah disediakan panitia.Pertemuan ini dihadiri pula oleh kepala bagian UKM dari kecamatan Cilodong, Depok.

\section{Jenis Produk.}

Jenis-jenis produk yang dipasarkan oleh para pelaku UKM Cilodong Berkarya didominasi oleh makanan, yaitu sebesar $48 \%$. Selain itu, produk kosmetik tidak digandrungi oleh para pelaku UKM Cilodong Berkarya Berkarya karena membutuhkan modal yang cukup banyak. Dari diagram ini, dapat dilihat bahwa hampir sebagian besar para pelaku UKM Cilodong Berkarya Berkarya bergerak dibidang F\&B. 


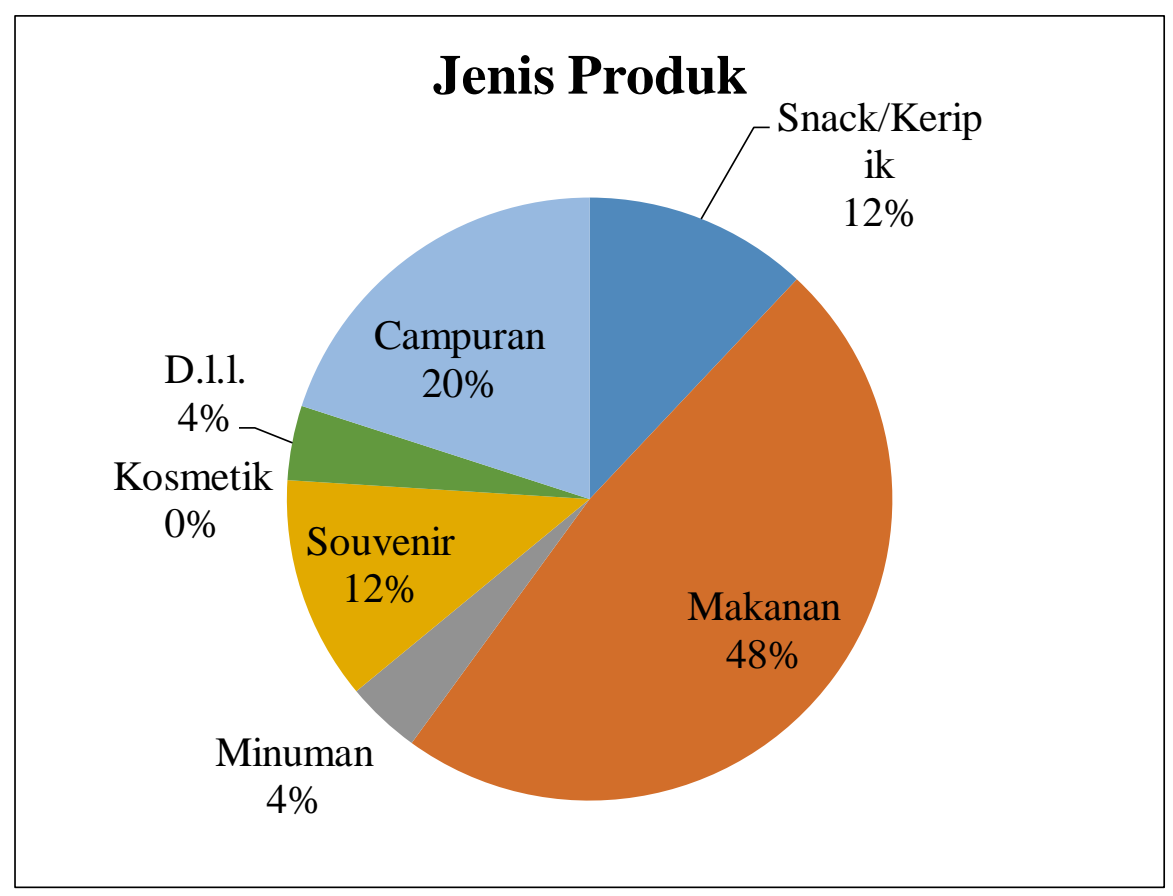

Gambar 2. Jenis Produk

Produk-Produk tersebut telah berhasil dipasarkan baik di lokal didaerah Depok, ataupun sudah ada yang merambah ke seluruh Indonesia, bahkan ada yang juga berhasil memasarkan ke beberapa negara tetangga, yaitu Malayia dan Singapura.

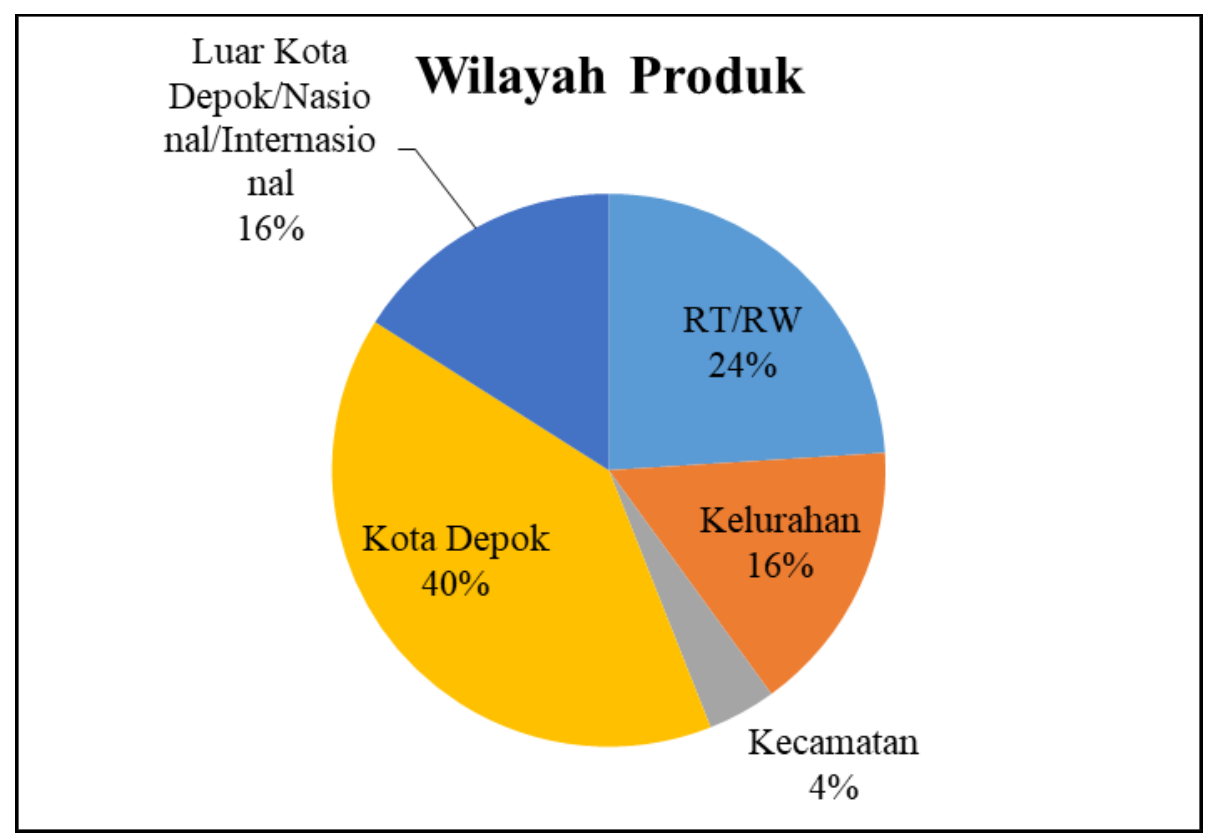

Gambar 3. Wilayah Produk

Berdasarkan diagram di atas, dapat diketahui bahwa 40\% produk-produk dari UKM Cilodong Berkarya Berkarya sudah dikenal oleh masyarakat Kota Depok. Selain itu, diikuti oleh produkproduk yang diketahui oleh RT/RW sekitar pemiliki produk sebesar 24\%. Hal ini menandakan bahwa produk-produk yang dipasarkan oleh UKM Cilodong Berkarya Berkarya berpotensi untuk menjadi produk unggulan kebanggaan Kota Depok. 
Seluruh pemilik produk-produk UKM Cilodong Berkarya Berkarya ingin supaya usahanya bisa berekspansi, baik ekspansi dari tingkat produksi, hingga kepada tingkat pemasaran diluar Indonesia. Selain itu, para pemilik produk juga ingin meningkatkan nilai brand awareness dari produk mereka, sehingga masayarakat dapat mengenal produk-produk ini dengan mudah (peningkatan brand awareness melalui identitasproduk dan merek). Sebanyak 52\% dari pemilik produk UKM Cilodong Berkarya Berkarya merasa bahwa kemasan produknya sudah menarik dan cukup diminati dikalangan pembeli. Akan tetapi, $48 \%$ pemilik produk UKM Cilodong Berkarya Berkaryamerasa bahwa kemasan produknya dinilai belum maksimal dan masih sedikit diminati oleh pembeli.

Hampir sebagian besar dari pemilik produk UKM Cilodong Berkarya tidak memiliki urgensi untuk me-redesign kemasan yang dimiliki. Hal ini dikarenakan para pemilik produk mempertimbangkan faktor anggaran yang dikeluarkan untuk membuat kemasan produk mereka selama ini. Selain itu, mereka menilai bahwa produk-produk yang dipasarkan sudah cukup dikenal dikalangan masyarakat. Sebesar $84 \%$ para pemiliki produk di UKM Cilodong Berkarya merasa optimis bahwa merek dari produk yang mereka pasarkan sudah dinilai cukup menarik bagi konsumen. Adapun hanya beberapa pemilik produk saja yang merasa bahwa merek produk yang dipasarkan kurang begitu menarik konsumen.

Sebesar $60 \%$ dari pemilik produk UKM Cilodong Berkarya Berkarya merasa bahwa merek dari produk mereka sudah memiliki ciri warna yang menarik bagi konsumen. sementaar $40 \%$ belum. Ciri warna ini didasari pada keterkaitan antara karakter warna dengan karakteristik produk yang dimiliki. Meskipun para pemilik produk optimisakan produk dan merek mereka, akan tetapi mereka tidak yakin bahwa tipografi (gaya tulisan) yang dimunculkan dalam merek masih kurang mewakilkan karakter produk dan merek mereka. Hal ini dibuktikan dari $72 \%$ pemilik produk UKM Cilodong Berkarya Berkarya merasa bahwa tipografi yang digunakan dalam merek mereka kurang menarik minat konsumen. Akan tetapi, sarana pemasaran mereka sudah didominasi dengan pemasaran via media sosial. Sebesar $84 \%$ dari pemilik produk UKM Cilodong Berkarya Berkarya, memasarkan produk mereka via media sosial, terutama aplikasi Whatsapp dan Facebook. Sementara $16 \%$ tidak menggunakan. Tentu dalam melakukan pemasaran via media sosial, pemilik produk harus memiliki strategi kreatif dalam melakukan pemasarannya.

\section{Redesain Kemasan Produk salah satu produk unggulan UKM Cilodong Berkarya}

Desain kemasan atau dapat disebut juga Packaging adalah salah satu dari sekian banyak hal yang harus menjadi pertimbangan strategis di ketiga elemen Positioning, Diferensisas, Brand pada suatu produk (Cravens,1996). Konsumen dapat dirangsang perhatiannya oleh daya tarik visual yang terlihat dalam produknya dengan memanfaatkan warna, bentuk, ilustrasi, dan tentunya mereknya, Sebuah kemasan berfungsi sebagai alat pembungkus, pembentuk citra, melindungi mengeluarkan, melindungi, menyimpan, mengindetifikasi dan membedakan sebuah produk di pasar (Naidoo, 2010. Adapun salah satu luaran dari kegiatan abdimas ini adalah memberikan rekomendasi redesain dari salah satu produk unggulan UKM Cilodong Berkarya yaitu Teh Aloe vera atau teh dari kulit lidah buaya. UKM Cilodong telah berhasil menciptakan teh lidah buaya dengan berbagai kemasana namun, untuk merebut pasar potensial milenial masih nampak konvensional. Sehingga ini perlu mendapatkan pendampingan untuk dapat menciptakan teh dalam kemasan yang lebih menarik. 


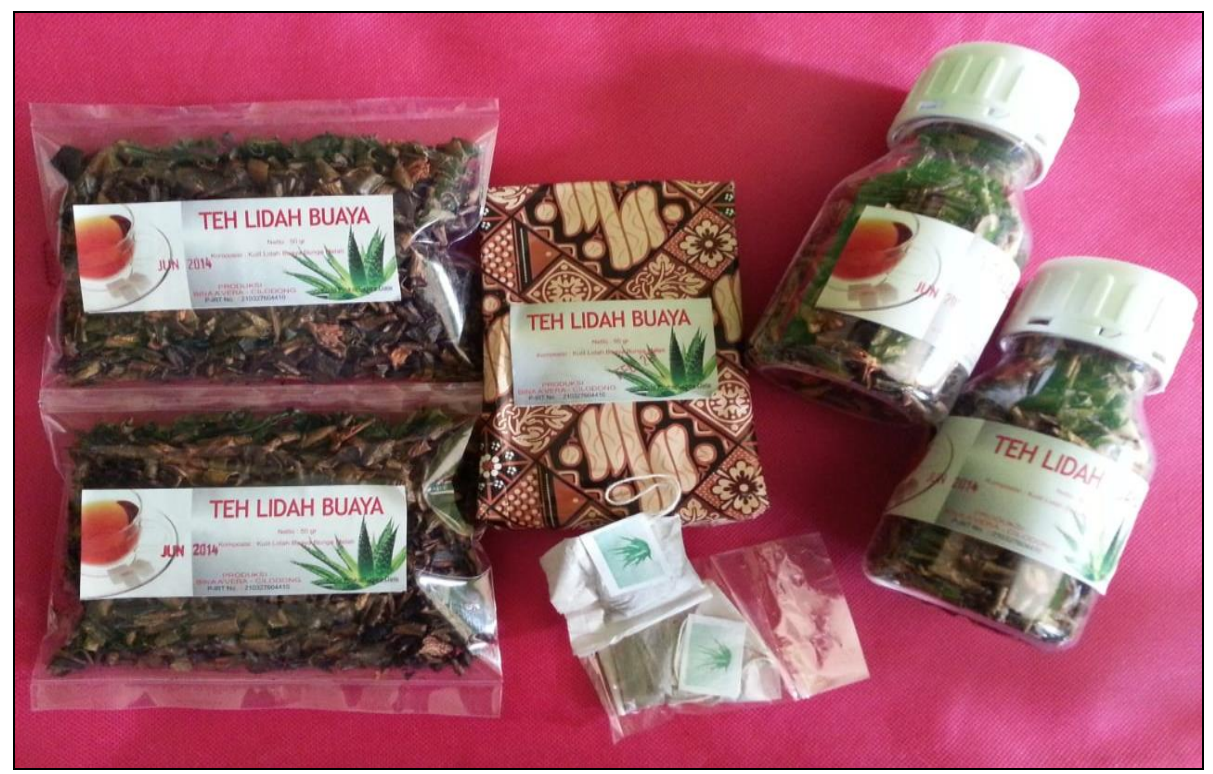

Gambar 4. Desain Kemasan Yang Lama dari Produk Teh Lidah Buaya

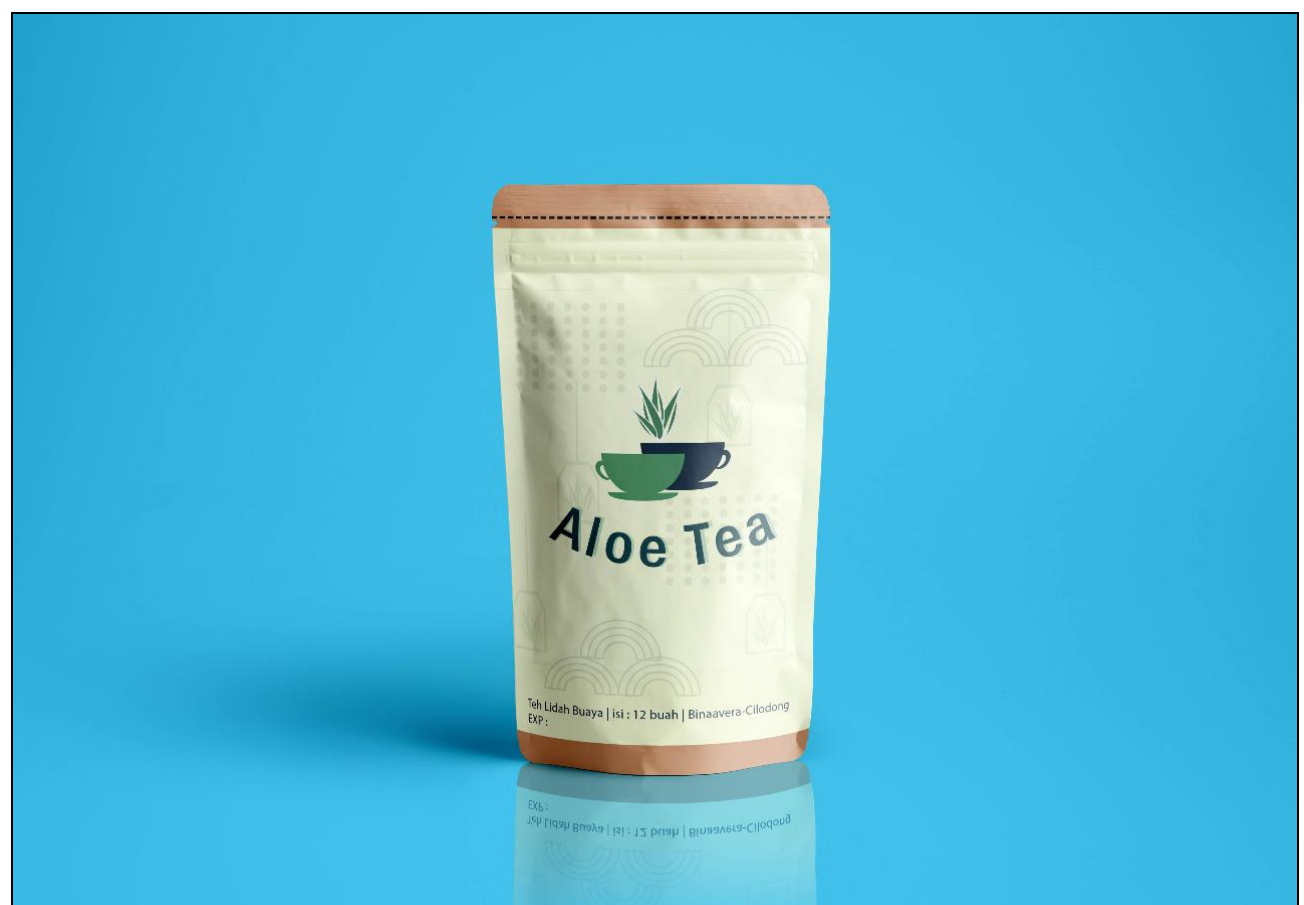

Gambar 5. Desain Kemasan Yang Lama dari Produk Teh Lidah Buaya

\section{KESIMPULAN DAN SARAN}

Hasil dari pengabdian masyrakat tentang Redesain kemasan berkaitan pada bentuk, struktur, material, warna, citra, tipografi, dan elemen elemen desain dengan informasi produk agar produk dapat dipasarkan. Hal ini dibuktikan dengan melakukan Redesain kemasan pada salah satu produk unggulan Teh Aloe Vera dengan perbandingan kemasan lama dan kemasan baru yang didesain lebih menarik, sehingga memiliki fungsi yang maksimal berlaku untuk membungkus, melindungi, mengirim, mengeluarkan, menyimpan, mengidentifikasi, dan membedakan sebuah produk di pasar . 


\section{UCAPAN TERIMA KASIH}

Ucapan terima kasih kepada para peserta pelatihan dalam Abdimas ini yaitu anggota UKM. Juga disampaikan kepada Ketua LPPM UPN Veteran Jakarta, aats dukungan terhadap terlaksanaanya kegiatan Abdimas Tahun 2019 ini.

\section{REFERENSI}

Cravens, D. W. (1996). Pemasaran strategis . ed 4. Jilid 1. Jakarta: Erlangga.

Antti, H., Madupu,V., Yavas, V., \& Babakus, E (2005). Cooperative Strategy, knowledge intensity and export performance of small and medium sized enterprises. Journal of World Business ,40 (2) 124-138.

Primiana, I. (2009). Menggerakan sektor riil ukm dan industri bandung: Alfabeta

Jonsson, S. \& Lindbergh, J.(2010). The impact of institutional impediments and information and Knowledge echange on SME's investments in international business relationships.International Business Review. 19. (6) 548-561.

Naidoo, V. (2010). Firm survival through a crisis: The influence of market orientation, marketing innovation and business strategy. Industrial Marketing Management 39 (8). 1311-1320.

Pressey, A.D., Winklhofer, H. M. , \& Tzokas, N. X. (2009) Purchasing practices in small- to medium- sized enterprises: An examination of strategic purchasing adoption, supplier evaluation and supplier capabilities. Journal of Purchasing \& Supply Management ,15.214-228.

Primiana, I. (2009). Menggerakan sektor rill ukm \& industri. Bandung; Alfabeta 